Article

\title{
Digitalization and the Decoupling Debate: Can ICT Help to Reduce Environmental Impacts While the Economy Keeps Growing?
}

\author{
Tilman Santarius $1,2,3, * \mathbb{C}$, Johanna Pohl ${ }^{4}$ and Steffen Lange ${ }^{1,5}$ (D) \\ Institute for Ecological Economy Research, Potsdamer Str. 105, 10785 Berlin, Germany; steffen.lange@ioew.de \\ Einstein Centre Digital Futures, Wilhelmstraße 67, 10117 Berlin, Germany \\ 3 Department of Social Transformation and Sustainable Digitalization, Technical University of Berlin, \\ Marchstraße 23, 10587 Berlin, Germany \\ 4 Centre for Technology and Society, Technical University of Berlin, Kaiserin-Augusta-Allee 104, 10553 Berlin, \\ Germany; pohl@ztg.tu-berlin.de \\ 5 Resource Economics Group, Humboldt-Universität zu Berlin, Unter den Linden 6, 10099 Berlin, Germany \\ * Correspondence: santarius@tu-berlin.de
}

Received: 23 June 2020; Accepted: 7 September 2020; Published: 11 September 2020

\begin{abstract}
Digitalization can increase resource and energy productivities. However, the production and usage of information and communication technologies (ICTs) require materials and energy, and the application of ICTs fosters economic growth. This paper examines whether digitalization helps or hinders an absolute decoupling of environmental throughput from economic growth. The paper combines the literature on "green IT" and "ICT for green" with studies on decoupling, i.e., the relationship between economic growth, technological change, and environmental throughput. The paper identifies several strains of the decoupling debate and connects them to the environmental implications of digitalization. We focus on the relation between digitalization and (1) the question of finite non-renewable energies, (2) the environmental Kuznets curve, (3) the role of energy consumption for economic growth, (4) efficiency improvements vis-à-vis rebound effects, and (5) the role of general purpose technologies for resource and energy demand. We find that the empirical basis regarding digitalization's relation to these four aspects is still weak and hence, further research is needed. Comparing the mitigating and the aggravating impacts of digitalization, we conclude that a more active political and societal shaping of the process of digitalization is needed to make ICT work for global environmental sustainability.
\end{abstract}

Keywords: decoupling; economic growth; green growth; degrowth; ICT for sustainability; green IT; Kuznets curve; general purpose technologies; limits to growth; energy economics

\section{Introduction}

In many countries of the world, particularly industrialized countries, environmental throughput has increased during the past years and decades [1]. For example, greenhouse gas (GHG) emissions increased from 2000 to 2010 by $2.3 \%$ per year compared to $1.3 \%$ per year from 1970 to 2000 [2]. If certain environmental boundaries are not to be transgressed [3], the rise in resource use and environmental impacts cannot continue at the current rate, but rather has to decrease. According to an IPCC report, annual GHG emissions need to decline to $50 \%$ of 2010 levels by 2050 in order to limit the global temperature rise to between 1.5 and 2 degrees Celsius [2].

The size of the economy has also increased in the past, both on a global scale as well as for individual countries. While there is a consensus that the increase of environmental throughput needs to come to an end, it is controversially discussed whether economic growth should continue 
or not e.g., [4]. This debate needs to be differentiated between high-income and middle/low-income countries. In high-income countries, arguments in favor of economic growth are that it is necessary to achieve a high level of employment [5], to finance social security systems and state expenditures [6], and to facilitate investments in green production [7-10]. On the other hand, it is put forward that strong environmental regulations [11] or reductions in average working hours could prevent unemployment in non-growing economies [12]. It is argued that further economic growth does not increase well-being empirically (based on subjective well-being research, see for example [13]), in particular, because additional consumption does not lead to additional utility as it is primarily conspicuous consumption [14]. In countries with lower incomes, these counterarguments do not apply or to a lesser degree. Therefore, the case for economic growth is stronger and economic growth is often regarded as necessary to achieve high welfare and a green(er) economy $[9,15]$.

So far, different conclusions have been drawn from these considerations. (1) If one agrees that environmental throughput needs to decline and economic growth is necessary to invest into transforming unsustainable modes of production and consumption towards green alternatives, strategies for decoupling economic growth from resource use are the best way to achieve environmental sustainability. The feasibility of such decoupling has been investigated by various authors e.g., $[1,7,9,15-20]$. Particularly, it has been noted that neither a "relative decoupling" nor an only slight "absolute decoupling" of economic growth from environmental impact is enough, at least in industrialized countries, but that a sufficient absolute decoupling ( ), [16] (p. 2), [21] (p. 33), [22] (p. 59)) is needed-i.e., a decoupling that is fast enough and deep enough to reach important sustainability goals. (2) If one does not believe that such a sufficient absolute decoupling is possible, one has to analyze the drivers of economic growth and identify ways to eventually limit those, while at the same time finding ways to secure investments into green transformations and high well-being without further economic growth. These endeavors have been discussed in debates about post-growth or degrowth, e.g., [4,5,14,22-26].

In this paper, we address both of those considerations and link them to the debate about digitalization. By the process of digitalization, we broadly understand the increased use of digital devices and algorithm-based applications in many areas of economic and social life. Digitalization is often attributed to increase energy and resource efficiency and dematerialize production and consumption patterns [27]. The general point of departure of this article is that the process of digitalization may challenge both: the debates about decoupling, as well as the debates about green growth versus degrowth.

As for decoupling, several studies outline both opportunities but also limits of digitalization to increase energy and resource efficiencies and dematerialize patterns of production and consumption e.g., [27-30]. We review these lines of reasoning and link them to the core arguments of the (conventional) decoupling debate in order to investigate whether digitalization alters the prospects for decoupling. Note that we focus on the need to reduce resource use, energy, and associated impacts in absolute terms. Therefore, we do not address the prospects for relative decoupling but focus on absolute decoupling, particularly in high-income countries [20,31,32].

Our structure is as follows. In Section 2, we briefly present an empirical overview of the long-term developments of information and communication technology (ICT) sector growth, economic growth, and environmental impacts according to certain indicators and selected country groups. In Section 3 , we identify core arguments and state of literature of several decades of decoupling debate(s). On this basis, Section 4 analyzes whether and to what extent digitalization mitigates or aggravates the prospects for the absolute reduction of energy and resource use. In Section 5, we discuss our findings. Given that the lessons learned in Sections 4 and 5 suggest that digitalization will not contribute to a sufficient absolute decoupling in the necessary timeframe, Section 6 outlines key research avenues to make digitalization work for environmental sustainability. 


\section{Empirical Developments of Digitalization, Environmental Impact, and Economic Growth}

As a starting point, we have analyzed long-term country-specific data (1995-2017) in order to identify the developments of economic growth, ICT sector growth, energy demand, and $\mathrm{CO}_{2}$ emissions in the recent past. Figure 1 presents those correlations for the group of $28 \mathrm{EU}$ countries, the United States, China, and India.

EU 28

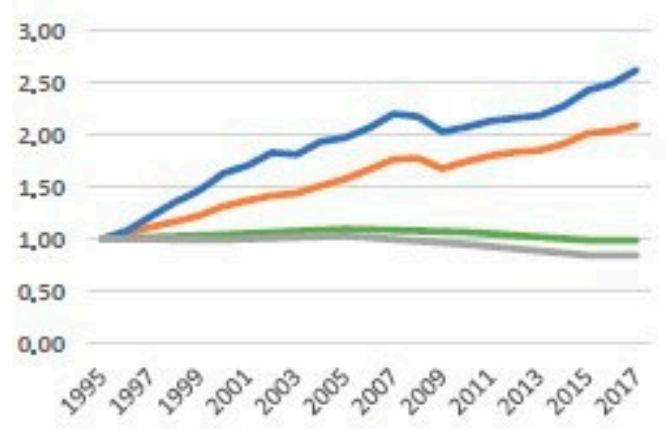

(a)

\section{India}

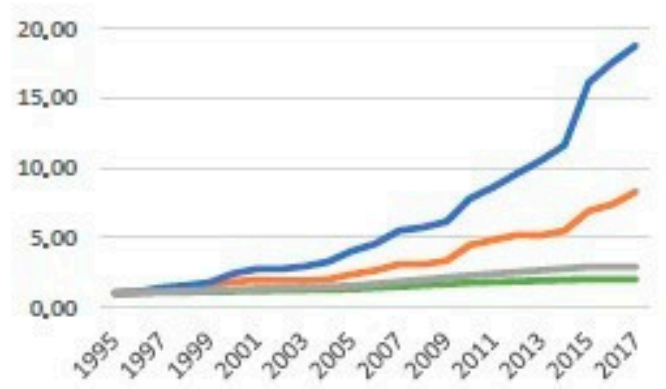

(c)

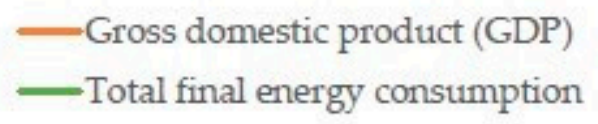

\section{United States}

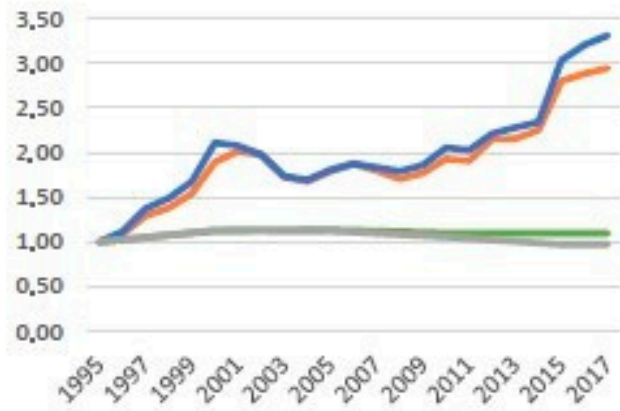

(b)

\section{China}

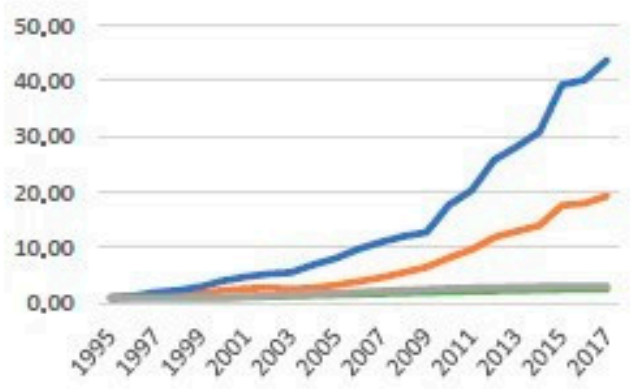

(d)

Figure 1. Empirical developments of digitalization, economic growth, and environmental impact for selected countries. This graph shows economic growth, energy consumption, growth of the ICT sector and $\mathrm{CO}_{2}$ emissions from 1995 to 2017 for (a) EU 28, (b) US, (c) India and (d) China (Index 1995 = 1). GDP and Value added of the total ICT sector are in Millions of current EUR PPS (Monetary values are expressed in euros and Purchasing Power Standards (PPS) at current prices). Energy Total Final Consumption is measured in Mtoe. $\mathrm{Co} 2$ emissions from fuel combustion are measured in $\mathrm{Mt}$ of $\mathrm{CO}_{2}$.

For all presented countries, ICT sector growth (i.e., growth in ICT value added) outnumbers overall GDP growth. This trend is mirrored by results from other studies, which also show that economies are increasingly digitalized [33,34]. Yet, while the ICT sector growth is disproportionally fast in the EU and in particular in China and India, ICT growth is only slightly faster than GDP growth in the US.

Regarding energy and $\mathrm{CO}_{2}$ emissions, the results also differ between countries and regions. In the EU28 and the USA (early industrialized countries), both stay roughly constant or decrease slightly. Comparing 1995 with 2017, the EU has experienced a 1\% drop in final energy consumption, while it has grown in the US by $10 \% . \mathrm{CO}_{2}$ emissions have slightly decreased for both-in the EU by $16 \%$ and in the 
US by $3 \%$. The developments have been rather different in China and India. Energy consumption has increased significantly in both countries: in China by $149 \%$ and in India by $100 \% . \mathrm{CO}_{2}$ emissions have also grown, in China by $211 \%$ and in India by $188 \%$. Of course, these increases in the two countries have been accompanied by much higher economic growth rates than in the EU and the US.

Overall, the developments show that economic growth and a digitalization of the economy have been accompanied by relative-and in some cases even a slight absolute-decoupling of energy consumption and $\mathrm{CO}_{2}$ emissions. Of course, these are merely developments and no causal inference can be made. Therefore, and in order to deeper understand the interrelationships between digitalization, environmental impacts, and economic growth, we will now dive into a qualitative analysis that intertwines findings from the "decoupling debate" with findings from the more recent "ICT for sustainability" literature and identify factors that either mitigate or aggravate the chances for a sufficient absolute decoupling.

\section{State of Literature: Key Arguments of the Decoupling Debate}

In the following section, we summarize key arguments from various strains of the decoupling debate. Without claiming to be exhaustive, we focus on five strains of that debate: the "limits to growth" debate, which started with a seminal study with the same title in 1972 (Section 3.1); the debate about the environmental Kuznets curve (EKC), which has been the key reason in the debate on structural economic change and environmental impacts (Section 3.2); the debate on the role of energy as a production factor for economic growth, including both views from energy economics and ecological economics (Section 3.3); the debate on energy efficiency improvements and rebound effects as one particular focus of the role of energy for growth (Section 3.4); and finally, the debate on the role of general purpose technologies for both environmental impacts and economic growth (Section 3.5). Afterward, in Section 4, we will revisit the key arguments of these five strains and link them to the question of digitalization.

\subsection{Limits to Growth and Scarce Resources}

The debate on the relationship between economic growth and material throughput experienced its first peak in the 1970s. In 1972, the report Limits to Growth [35] argued that natural resources will become scarce if the trajectories of economic growth and growth in material use continue. Focusing on the limited supply of non-renewable resources, early contributions within economics investigated the conditions for economic production in the long term. Three concepts to align ongoing economic growth with reduced environmental impacts were put forward: "substitution, resource-augmenting technical progress, and increasing returns to scale" [36] (p. 134). Note that all three of these concepts refer to technological solutions. Substitution means that natural resources are to be substituted by another production factor, in particular physical capital [37]. Resource-augmenting technical progress signifies that new technologies facilitate the same amount of production with less natural resources [38]. Increasing returns to scale imply the more efficient use of natural resources for larger levels of production. In the end, these discussions showed that the only way to facilitate constant or even rising production in the long run, while assuming a finite non-renewable resource base, is by continuously increasing resource productivity. How fast it has to increase depends on the combination of the size of production, the stock of natural resources, and the time horizon [36].

\subsection{Environmental Kuznets Curve}

The concept of the environmental Kuznets curve (EKC) gained momentum with the evolving sustainability debates in the late 1980s and 1990s [39,40]. The original Kuznets curve postulates that income inequality first rises and then decreases in the process of economic development. Similarly, the EKC suggests that environmental impacts rise and then decrease in growing economies [41]. Hence, it can be considered a strain of the decoupling debate, because arguments based on the EKC assume that environmental impacts would decrease with rising economic growth, at least in industrialized 
countries. Two key explanations for this decoupling have been brought forward in the EKC debate. The first directly refers to Kuznets's [42] argument on the direction of sectoral change: environmental impacts are low in economies with a high share of agriculture. When the share of industrial production increases, so do environmental impacts. Yet the key assumption of the EKC is that when a potential subsequent transition to a service economy takes place, environmental intensity would decrease again $[43,44]$. The second explanation of the EKC refers to the ability and willingness to pay for a cleaner environment, which are affected by rising incomes, increased information about environmental impacts, and changing values and norms. According to Dinda, "[W]hen a country achieves a sufficiently high standard of living, people attach increasing value to environmental amenities" [45]. Hence, people are willing to spend more of their income for greener products and a cleaner environment.

Overall, meta-analyses on the various empirical contributions to the EKC deliver mixed results. While some research found an EKC for specific environmental aspects, e.g., [46-48], Smulders et al. [49] point out that "[t]he empirical literature on the EKC [...] is huge and far from unambiguous" [49] (p. 440). Stern concludes: "It seems that emissions of most pollutants and flows of waste are monotonically rising with income, though the 'income elasticity' is less than one and is not a simple function of income alone" [41] (p. 1435). Caviglia-Harris et al. [50] and Markandya et al. [51] come to the conclusion that global environmental problems such as the environmental footprint or greenhouse gas emissions do not follow an EKC.

\subsection{Role of Energy for Economic Growth}

Another strain in the decoupling debate focusses on the relationship between economic growth and energy. Empirically, gross energy demand and GDP appear highly coupled in the vast majority of countries worldwide [52]. However, the question is whether this could be different in the future. This debate goes back to the early oil crisis in the 1970s, became a key topic of the subdiscipline of energy economics throughout the 1980s (e.g., [53,54]), and remains heavily debated until today [55]. The key question is: is energy of particular importance to economic growth, or can it be easily substituted so that economic growth can be decoupled from energy use? Two arguments are central in that debate.

First, the output elasticity of the production factor of energy is discussed, but remains unsolved between different schools of thought. In neoclassical growth theories, energy plays a limited role and, therefore, the output elasticity of it is small [56]. Other authors argue that energy plays an important role in the level of production despite its low cost share compared to capital and labor [57,58]. Not only the quantity of energy demand but also the shift from low-quality energy carriers (i.e., wood, coal) to high-quality energy carriers (i.e., electricity) are key drivers of growth [56,59]. Second, a long-standing debate investigates whether the production factors capital and energy relate like "substitutes", so that capital actually replaces energy, or whether they rather relate as "complements", so that increased investments in, or spending of capital bring about an increased demand for energy [60]. Regrettably, the empirical literature is far from uniform on this question and cannot even agree on a range of the elasticity in question [61,62]. Hence, the debate about whether energy and economic growth can be decoupled remains unsolved.

\subsection{Energy Efficiency and the Rebound Effect}

One particular focus of the energy-growth debate centers on the role of energy efficiency improvements for economic growth, which relates to the phenomenon of the rebound effect [63-65]. It is well documented that the history of industrialization brought about continuous efficiency improvements in the conversion of energy resources to energy services (e.g., coal/oil/gas to heat/power/light), but also in the provision of energy services to utility and value $[66,67]$. If these efficiency improvements lead to rebound effects, i.e., an increase in the demand for energy services, such energy efficiency improvements play out as a driver of economic growth. At the same time, parts or all of the technical savings potential can be "eaten up" by the increased demand for energy. If rebound effects are high, the contribution of energy efficiency improvements to decouple economic growth from energy consumption is limited. 
The estimation of the overall size of rebound effects varies highly across studies. At one end of the spectrum, it is stated that "most of the economic growth of our Western civilization in the past 200 years stems from the rebound effect" [66] (p. 233). In a similar vein, other rebound researchers believe that improvements in energy conversion technologies would contribute to increasing economy-wide energy demand over and above the initial level-a phenomenon that is termed backfire [53,68-70]. At the other end of the spectrum, some researchers argue that the contribution of rebound effects to energy consumption is relatively insignificant, e.g., [71-74]. Most rebound researchers appear to position themselves somewhere in the middle, finding that rebound effects do not generally lead to backfire, but that they are high enough to countervail a sufficient absolute decoupling of energy demand from economic growth [21,75-78].

\subsection{General Purpose Technologies}

Another strain of research focusses on the specific role of "general purpose technologies" (GPTs). In a comprehensive analysis, Lipsey et al. [79] classify 24 different technologies, including the steam engine, railway, electricity, automobile, airplane, and computer, but also "organizational technologies" such as mass production or lean management, and others [79] (p. 132). According to Lipsey et al. [79], GPT can be assigned characteristics such as genericness, scope for improvement, multiple applicability, and complementarity to existing technologies. Other definitions of GPT focus more on criteria such as pervasiveness and innovation spawning [80].

For the decoupling debate, three key findings from research on GPT can be distinguished. (1) Particularly during the expansive phase of a given GPT, its environmental impact strongly depends on the energy intensity of that GPT. (2) The impacts of GPT are pivotal explanatory factors of long-term economic growth: "One of the most important aspects of GPT is that they rejuvenate the growth process by creating spillovers that go far beyond the concept of measurable externalities" [80] (p. 100). (3) These positive effects on economic growth are only temporary for a single GPT [79]. Regarding the relationship between energy use and economic growth, Lipsey et al. [79] postulate that these function as complements, not as substitutes. Overall, research on GPT suggests that the contribution to decoupling is limited. It should be noted, however, that there is still little research on this issue.

\section{Digitalization, Resource Use, and Environmental Impacts}

In this section, we revisit the five strains of the decoupling debate summarized in Section 3 and link them to the role of digitalization (ICT) for economic growth and environmental impacts. Each subsection is condensed in a preliminary conclusion for each strain of the decoupling debate, which we merge in the overall discussion in Section 5.

A few studies have attempted to balance ICT's positive and negative environmental impacts throughout all sectors $[28,81,82]$. However, these studies do not seem reliable, and methodological developments for a comprehensive and consistent synopsis are still at the beginning stages [81]. In order to come closer to an answer, in the following, we revisit the aforementioned arguments of the decoupling debate(s) with a focus on digitalization's effects on resource use, energy demand, and economic growth.

\subsection{ICT and Scarce Resources}

The potential end of (non-renewable) resources as an absolute limit to economic growth has been one key argument since the early debates on decoupling (see Section 3.1). Digitalization is supposed to help prevent this absolute limit by increasing resource efficiency. At the same time, it is clear that the production (and application) of ICT itself requires resource consumption. There is little research to date that attempts to quantify ICT's resource demand, both regarding past and future demand.

Marscheider-Weidemann et al. [83] investigate changes in raw materials demand between 2013 and 2035 due to technological change. Among the technologies investigated are eight emerging ICT technologies. They identify sixteen raw materials of particular relevance, such as lithium, 
dysprosium/terbium, rhenium, tantalum, cobalt, germanium, scandium, and neodymium. Driven by the growing demand for ICT and of various other emerging technologies, the demand for several of those resources is projected to exceed the total 2013 production levels by 2035 [83]. Malmodin et al. [84] present high-level estimates of the worldwide ICT sector's material footprint for 2015, including electronic and media devices. The results show that the sector has a rather low impact on the global usage of sector-relevant materials (representing about $0.5 \%$ of the global annual usage of the selected materials). However, for single materials such as gallium, germanium, and indium, the ICT sector represents the dominant use with as much as $80-90 \%$ of global usage [84]. A study by Henckens et al. [85] focuses on the scarcity of metals and clusters over 40 metals according to their geological scarcity. Among the five metals identified as "very scarce" or "scare", several materials relevant to the ICT sector can be found [85]. A study on the material effects of emerging data storage technologies shows low demand for critical elements compared to their global production rates. However, a significant increase in hard disk drive production could affect the supply chains of neodymium and platinum-group metals [86]. Vaalma et al. [87] estimate that with growing demand for lithium-ion batteries, lithium and cobalt could become scarce by 2050. The increasing demand is partly due to ICT devices, but also stems from e-mobility and other applications [87].

Research on the substitution of certain elements in the ICT sector is at an early stage. Instead of lithium-ion batteries, for instance, sodium-ion batteries could be a possible substitute for certain applications. However, portable ICT devices are still expected to require lithium-ion or other cobalt-rich batteries [87]. Investigations on substitution opportunities of rare earth metals in low-carbon technologies such as lighting, wind turbines, or electric vehicles show mixed results [88-90]. While in both the wind industry and lighting sector, technology development has the potential to lower the demand of rare earth metals $[88,90]$, the opposite has been found for the electric vehicles sector. Growing demand for electric vehicles is expected to also increase the demand for rare earth metals [89].

Preliminary conclusion: The ICT sector's demand for resources and energy only accounts for a small share of global demand. However, several resources that are important for ICT devices are scarce or expected to become scarce within the next decades. As of current knowledge, a stark scaling up of production, i.e., for millions of digital devices in the upcoming Internet of Things, seems challenging at least. There is literally no evidence for an increasing share of renewable materials in the production of ICT devices. Research on substitution potentials of certain critical materials is still very weak-recalling the state of research during the limits to growth debate in the 1970s. These facts support the argument that digitalization rather aggravates the challenges for decoupling regarding natural resources.

\subsection{ICT and the Kuznets Curve}

The first argument for the environmental Kuznets curve is that environmental impacts decrease when economies develop from primarily producing industrial goods to focus on the services (see Section 3.2). Several studies suggest that ICT leads to particularly high growth rates in various service sectors [91-93]. According to Sapprasert [94], ICT on average leads to higher growth rates of productivity and profitability in service sectors compared to manufacturing sectors. In an increasingly ICT-driven industry, ICT services and maintenance gain in importance in many areas of manufacturing [95]. ICT has also been argued to play a role in the division of labor, leading to stronger tertiarization in countries of the Global North and stronger industrialization in other countries [96-98]. However, some authors argue that certain digital technologies, such as 3D printing, may lead to a relocation of manufacturing back into the Global North in future years [99-101]. From a global environmental point of view, the central question is whether ICT may spur a global environmental Kuznets curve, rather than relocating dirty production into other parts of the world. Research on such global developments is still missing.

The second argument for an EKC is that the level of information and the prevalence of environmental values and norms increase with the level of economic wealth and, therefore, the ability and willingness to pay for environmental protection and more sustainable forms of production and 
consumption rises. There is little doubt that digitalization carries the potential to increase the amount, and also the granularity, of information about more sustainable forms of production and consumption. Consumers can search the internet or use certain blogs or apps (e.g., apps based on bar code scanning) to access information about product derivation and characteristics, such as a product's ecological footprint [102-104]. More information and more timely information (i.e., in real-time; while shopping), as well as better visualization of information through apps, increase the chances for informed consumer decisions [105-107]. This increases the ability of consumers to choose more sustainable ways of needs satisfaction. Digitalization also improves the ability of firms to serve consumers' interest in sustainable consumption. By way of digital supply chains, companies may take better control of production standards of supply components $[108,109]$. ICT can also improve coordination and communication between producers and consumers and, hence, more readily include consumer preferences in the design, production, and marketing of products [110-112].

However, as the role of information in consumer choices has been well researched in various fields, it cannot be stated that improved information generally leads to more sustainable consumption behavior $[113,114]$. At the same time, countervailing forces are at work: information provided by online marketing and personalized advertisement serves as an effective tool to drive consumer choices towards more consumption and fewer sustainability concerns [115-118].

Preliminary conclusion: Existing evidence suggests that digitalization spurs a further tertiarization of the economy in countries of the Global North. The global effect, however, is unclear. Digitalization improves the amount and quality of information about production standards and more sustainable consumption opportunities. At the same time, it remains open whether digitalization actually changes social values and norms towards sustainability and, hence, improves the willingness to pay for more sustainable products and services.

\subsection{ICT and Energy Demand}

As we have outlined in Section 3.3, both the price of energy as well as changes in the kinds of energy carriers used may impact economic growth and, hence, resource demand. Studies on the energy consumption of the ICT sector show a steadily and quickly increasing energy demand over recent years [119-121]. According to some scenarios, ICT's future electricity consumption is expected to rise from $1500 \mathrm{TWh}$ ( $8 \%$ of global electricity consumption) in 2010 to $5700 \mathrm{TWh}$ (14\% of global electricity consumption) in $2030[119,122]$. In contrast, other authors find that the operational electricity demand of the ICT sector remained roughly constant at around 800 TWh between 2010 and 2015 (4.3\% of global electricity consumption for 2010 and 3.8\% for 2015) and was slightly rising between 2015 and 2018 [123].

Next to the electricity consumption of ICT itself, the question is how the electricity consumption for an entire economy is related to digitalization. For OECD countries, a panel data analysis for the years 1985-2012 by Salahuddin und Alam [124] suggests that growing ICT use results in increasing both electricity consumption and economic growth. This corresponds to the result of a previous panel data analysis by Saidi et al. [125]. Sadorsky [126] finds a positive relation between the share of internet users and electricity demand. Digitalization, hence, tends to go along with higher electricity consumption.

However, several authors find that ICT can be associated with decreasing overall energy consumption [127,128] and can substitute energy as a production factor [129]. It may therefore be, that digitalization supports a switch from other energy carriers towards electricity [130]. According to the arguments raised by Stern and Kandler [56,59], this may spur further economic growth and increases in resource demand. This goes hand in hand with the empirical result that digitalization is associated with higher levels of economic growth (see Sections 2 and 3).

Preliminary conclusion: Studies suggest both a complementary relationship of ICT electricity demand and economic growth and a shift towards electricity as the main energy carrier due to digitalization. While the basis of literature is still weak, these facts support the argument that digitalization rather aggravates the challenges for decoupling regarding energy demand. 


\subsection{ICT, Efficiency Improvements, and Rebound Effects}

Regarding the potential of ICT to save energy and resources, several studies suggest that the application of digital devices and programs can increase efficiencies in several areas, including the important sectors agriculture, transport, and industrial production, e.g., [28,131]. Sui and Rejeski [132] call these positive environmental effects of ICT the "three D's for the new economy": dematerialization, decarbonization, and demobilization. Berkhout and Hertin [133] describe the use of ICT as an enabling technology for reducing environmental throughput. Many other sources of "grey literature" promise that the virtualization by way of ICT would also lead to dematerialization and provide for a win-win of the economy and the environment [134-136].

In fact, the application of ICT tends to increase energy and resource efficiencies when looking at specific goods or services, as shown by several empirical studies. The following references highlight some examples. Coroama et al. [137] evaluate the GHG abatement potential of virtual conference meetings, where the exchange between two slots was provided by a video conferencing system. The results indicate a GHG abatement potential of 37 to $50 \%$ compared to an on-site conference. Moberg and colleagues evaluate the energy-saving potential of electronic invoicing [138] and the environmental advantages when switching from conventional newspapers to checking news online [139]. Other studies highlight the potentials savings from streaming videos versus DVD rental when driving to the rental outlet by car $[140,141]$. Beier et al. [142] investigate whether the Industrial Internet of Things enables more sustainability in industry. The authors cite additive manufacturing technologies such as 3D printing, which enable resource-efficient manufacturing of prototypes and products with small lots and high variances.

However, several studies also show mixed results. In a study of the Japanese book sector, Williams and Tagami [143] compared e-commerce and conventional retailing. Results show that in urban areas, retailing uses significantly less energy per book. In rural areas, both systems use a similar amount of energy. Other studies on energy savings in e-commerce also show ambiguities, e.g., [144-146]. Opportunities for resource reduction in the production sector also arise from increasing supply chain transparency, improved recycling processes, and predictive maintenance.

In addition to those and many other studies showing the positive effects of efficiency improvements or mixed results, there are strong arguments that increases in efficiency are often countervailed by negative environmental effects, such as incomplete substitution, rebound effects, and induction effects [105,147-149]. For instance, potential savings from video streaming vis-à-vis DVD rental are likely countervailed by the increased hours watched [27]. In more general terms, the ICT sector may be particularly prone to high rebound effects $[30,65,150]$.

Preliminary conclusion: Literature abounds on energy saving potentials from ICT-based efficiency improvements in various production and consumption processes. Yet, those studies focus on micro-level effects only and neglect any global effects at the macro-level. Additionally, they mostly describe potentials rather than actual developments. Theoretical arguments for incomplete substitution and potential rebound and induction (growth) effects are strong and are backed by anecdotal evidence, while empirical evidence on the causal link between digitalization and rebound effects has not yet been sufficiently researched on empirical grounds. These ambiguous facts suggest that ICT's overall effect on energy consumption via energy efficiency and rebound effects still remains unclear.

\subsection{ICT as One or Several General Purpose Technologies}

Research on GPT stresses that the characteristics of a given GPT strongly influence both the speed of economic growth and the change in energy intensity throughout the economy, particularly in its early "take-off" phases (see Section 3.5; [79]). The relation of ICT to these aspects, therefore, has a strong impact on the prospects to decouple economic growth from energy consumption in the near future.

There is an almost unanimous agreement for a positive relation between digitalization and economic growth. Several studies find a positive relation between digitalization and the level of GDP [151] and the speed of economic growth [124,152-155] for a diverse set of countries ranging from 
the US over OECD countries to South Asian and Latin American economies. In addition to these studies at the macro-level, various micro-level studies suggest increased investments and profits for businesses due to digitalization $[28,91,93,95,156,157]$.

On the other hand, different studies suggest that digitalization contributes to increased unemployment, as well as a polarization of income [158-161]. High income inequality usually dampens aggregate demand and economic growth [162]. So, despite the significant number of studies suggesting a positive effect from digitalization on economic growth, in the future, this effect might be lower if distributional effects of digitalization on economic equality will countervail its growth potentials.

The literature regarding GPTs in general (Section 3.5) suggests that a GPT's impact on economic growth is mainly temporary. However, the question arises: can "ICT" be classified as one single GPT, or does it rather cover multiple GPTs? Several authors suggest that the computer (i.e., microprocessor), the Internet, mobile ICT equipment, and cloud computing might be considered as separate GPTs which are already in place, while machine learning ("artificial intelligence"), the (Industrial) Internet of Things, or virtual/augmented reality might be considered GPTs still in their beginning [163-166]. Accordingly, the expansive phase of ICT as multiple GPTs and their (temporary) impact on overall economic growth would span several phases, during which energy use and economic output would both significantly increase. Reports on the expected potential of cloud computing, big data analytics, artificial intelligence, automation, and robotics on future economic growth support the assumption that ICT may have a longer-term impact on economic growth $[28,91-93,95,98,124,156]$.

As for energy intensities, measured as energy input per unit of GDP (e.g., US dollars), producing and running ICT devices and applications is less energy intensive compared to former GPTs such as trains, cars, or airplanes see [67]; yet they are probably more energy intensive than GPTs such as the laser or "lean management" techniques. The energy intensity of ICTs as multiple GPTs can probably not be grasped by looking at single devices or applications, but by their sum. Since ICTs have an outstanding diffusion potential—-the number of devices and their pervasiveness in working life and everyday life is much higher compared to any former GPT except for electricity-their share in global electricity demand is already high today, and may increase significantly in the future (see Section 4.3). At the same time, as has been mentioned in Section 4.4, ICT has a far higher potential than former GPTs to reduce energy and resource demands in many sectors by way of efficiency improvements, optimization, and substitution. Comparing the GPTs "ICT" and "electrification", Jovanovic and Rousseau [167] suggest that the introduction of electrification was more pervasive, while ICT may be more efficiency increasing and innovative.

Preliminary conclusion: The process of digitalization yields not only one, but several GPTs. Their energy intensity is lower compared to former GPTs. However, due to high pervasiveness and diffusion, their aggregated effect on economic growth is likely to be strong and long term. Hence, also, the effects on global resource and energy demand are likely to be significant, in particular during each of the single GPT's expansive phases. These arguments suggest that at least during the coming one or two decades, digitalization rather aggravates the challenges for decoupling.

\section{Discussion: Lessons Learned on Digital Decoupling}

As we have seen, research about decoupling and digitalization is still at the beginning stages, and empirical quantifications covering various sectors and use cases are limited. It is not (yet) possible to draw a line under all beneficial and detrimental environmental effects and to fully answer whether, overall, digitalization facilitates decoupling or makes it more difficult.

In Section 2, we presented the empirical developments of ICT sector growth, economic growth, and environmental impacts which, amongst others, showed that a digitalization of the economy takes place, while a sufficient absolute decoupling is not taking place. Against this background, we have summarized five strains of the decoupling debate in Section 3 to provide qualitative analyses in order to understand these developments. The five strains have developed historically and often quite 
separately. Therefore, it is not obvious how they are connected and how each of them links to the role of digitalization (ICT). In order to shed light on the role of digitalization regarding decoupling, the most insightful connection between the different debates is the role of technology. The existing and anticipated technologies determine how fast resource use can be augmented and production factors can be substituted (see Section 3.1). The EKC implies a switch of the shares of technologies used from agricultural to industrial to service-related technologies (Section 3.2). Technological possibilities determine how far it is possible to use physical capital instead of energy (Section 3.3), and to what extent efficiency improvements deliver a more economical use of energy (Section 3.4). General purpose technologies have a strong impact on economic growth and its relation to energy intensity (Section 3.5). The impact of ICT on the relation between economic growth and energy consumption (in other words, on decoupling) is, therefore, how the digital technologies change these respective aspects.

Table 1 condenses the preliminary conclusions from Sections 4.1-4.5 as well as Section 5 and, hence, summarizes how digital technologies aggravate or mitigate the challenges of decoupling —structured along the five debates on decoupling. Additionally, the table encompasses open questions in this new domain of research on digitalization and decoupling.

Table 1. Digitalization and the decoupling debate—summary of key arguments.

\begin{tabular}{|c|c|c|c|}
\hline & $\begin{array}{l}\text { Digitalization } \\
\text { Aggravates the } \\
\text { Challenges for } \\
\text { Decoupling }\end{array}$ & $\begin{array}{c}\text { Digitalization Mitigates } \\
\text { the Challenges for } \\
\text { Decoupling }\end{array}$ & $\begin{array}{l}\text { Open Research } \\
\text { Questions }\end{array}$ \\
\hline \multirow[b]{2}{*}{ Limits to growth debate } & $\begin{array}{l}\text { Upcoming scarcities of } \\
\text { certain materials }\end{array}$ & \multirow[t]{2}{*}{-} & \multirow{2}{*}{$\begin{array}{l}\text { In how far does ICT } \\
\text { increase resource } \\
\text { efficiencies in other } \\
\text { sectors? }\end{array}$} \\
\hline & $\begin{array}{c}\text { Currently low/no } \\
\text { substitutability of certain } \\
\text { materials }\end{array}$ & & \\
\hline \multirow[b]{2}{*}{$\begin{array}{l}\text { Environ- mental Kuznets } \\
\text { curve debate }\end{array}$} & \multirow{2}{*}{$\begin{array}{l}\text { Improved personalized } \\
\text { marketing incentivizes } \\
\text { consumption }\end{array}$} & $\begin{array}{l}\text { Tertiarization of the } \\
\text { economy in high-income } \\
\text { countries }\end{array}$ & \multirow{2}{*}{$\begin{array}{c}\text { Does ICT go along with } \\
\text { tertiarization on a globa } \\
\text { scale? }\end{array}$} \\
\hline & & $\begin{array}{l}\text { Improved process and } \\
\text { product information } \\
\text { facilitates sustainable } \\
\text { consumption }\end{array}$ & \\
\hline Efficiency debate & $\begin{array}{l}\text { Potential for rebound } \\
\text { and induction effects } \\
\text { increase demand }\end{array}$ & $\begin{array}{c}\text { Potential for efficiency } \\
\text { improvements decreases } \\
\text { demand }\end{array}$ & $\begin{array}{l}\text { How strongly does ICT } \\
\text { increase energy } \\
\text { efficiencies in other } \\
\text { sectors? }\end{array}$ \\
\hline $\begin{array}{l}\text { Energy and economic } \\
\text { growth debate }\end{array}$ & $\begin{array}{l}\text { Shift towards electricity } \\
\text { as main energy carrier } \\
\text { spurs economic growth }\end{array}$ & $\begin{array}{l}\text { Shift from other energy } \\
\text { carriers towards } \\
\text { electricity (which has a } \\
\text { relatively high share of } \\
\text { renewables) }\end{array}$ & $\begin{array}{c}\text { Can ICT sector growth } \\
\text { be absolutely decoupled } \\
\text { from ICT energy } \\
\text { demand? }\end{array}$ \\
\hline \multirow{2}{*}{$\begin{array}{l}\text { General purpose } \\
\text { technology debate }\end{array}$} & $\begin{array}{l}\text { Complementary } \\
\text { relationship of ICT } \\
\text { energy demand and } \\
\text { economic growth }\end{array}$ & - & \multirow{2}{*}{$\begin{array}{l}\text { What is the long-term } \\
\text { impact of digitalization } \\
\text { on economic growth? }\end{array}$} \\
\hline & $\begin{array}{l}\text { Prolonged impact on } \\
\text { economic growth due to } \\
\text { several ICT-born general } \\
\text { purpose technologies }\end{array}$ & - & \\
\hline
\end{tabular}

Table 1 shows that we have at least as many questions as answers regarding the impact of digitalization on decoupling in the past. Regarding future developments, the overall result is even 
less clear. To summarize the state of knowledge, there is significant empirical evidence for the energy and resource use directly related to ICT-both have been rising in the past. In addition, there is clear evidence that ICT supports economic growth. Both aspects rather aggravate the problem of decoupling. We know less regarding the potential environmental benefits of ICT. It is unclear in how far the application of ICT actually improves energy and resource efficiencies throughout the economy and whether it spurs tertiarization worldwide (and not merely represents a division of labor between high-income and other countries). The ability to understand the impact of digitalization on decoupling rests to a large degree on the answers to these questions.

Taking both the empirical correlations (Section 2) and the conceptual arguments (Section 4) as they are, there are considerably more indications that digitalization aggravates the challenges for decoupling than mitigates them. Four aspects are central. (1) The resource and energy use of ICT is growing. While the overall resource use of the ICT sector is relatively small, its dependence on crucial materials may limit its spread in the medium run. (2) Whether digitalization initiated a strong tertiarization on the global scale (and not only within certain countries) is questionable. The expectation that ICT helps the environment significantly due to this mechanism does not seem probable. (3) More promising is that the application of ICT throughout the different sectors of the economy allows for large increases in energy and resource efficiency. This is the central potential of ICT to facilitate decoupling. (4) However, this is likely to be counteracted by rebound effects and economic growth. While the size of rebound effects is difficult to measure, the positive impact of ICT on economic growth is evident-making fast absolute reductions in energy and resource consumption difficult.

Hence, and notwithstanding the limited empirical evidence available, it seems unlikely that digitalization as it unfolds today improves the prospects of decoupling. In other words, digitalization might play a role in explaining relative decoupling but not absolute decoupling, which has taken place at least in the EU in the past 20 years (Section 2). Rather, our analysis suggests that digitalization increases absolute energy and resource consumption. If this is true, the experience of (slight) absolute decoupling has to be due to other factors than digitalization. To enhance the prospects of digitalization to support absolute decoupling, it is necessary to speed up increases in energy and resource efficiencies and at the same time limit rebound effects and economic growth. Another conclusion seems relatively safe to make: digitalization by itself does not lead to a sufficient absolute decoupling, i.e., a cut back of resource and energy demands and environmental impacts fast enough and deep enough to reach important sustainability goals, such as keeping global warming at or below 1.5 degrees Celsius. Hence, a more active shaping of digitalization appears needed, which involves policies and measures that intend to maximize digitalization's savings potential and to minimize respective countervailing forces.

\section{Conclusions and Further Research Needs}

Given our preliminary conclusions in Section 5 above, we would like to highlight four overall conclusions. First of all, our discussion shows that there is a strong need for further research to improve the empirical implications of digitalization on the prospects for decoupling. In particular, research is needed that examines the open research questions indicated in Table 1. Additionally, methods are needed that interrelate effects of digitalization on the micro-scale-e.g., improved efficiency, improved information on certain process and production standards, etc. - with effects on the macro-scale-e.g., economy-wide rebound effects, or the energy-growth nexus. For instance, digitalization may indeed contribute to improved energy efficiency on the micro-scale. However, mesoand macroeconomic effects may induce additional energy consumption elsewhere, so that economic growth and energy demand remain coupled at the macro-scale. Moreover, hands-on empirical research is needed with regard to several aspects, e.g., the substitutability of certain critical and scarce materials, or meta-analysis evaluating the efficiency potential of various digitalized products and services to bring together knowledge that is often selective and dispersed.

Second, we draw from the discussion and the lessons learned in our paper that calling for further empirical research will not solve the overall question discussed in this article. Additional theoretical 
research is needed, too. The complexity of the discussion and, in particular, the interdependencies of various and diverse implications of digitalization suggest that it will not be possible to ultimately empirically verify or falsify whether digitalization mitigates or aggravates the prospects for decoupling. For instance, the implications and dynamics set in motion by digital GPT cannot be fully determined empirically. The implications of digitalization are too complex and widespread in society for empirical research to deliver comprehensive (und unequivocal) results. Hence, more profound theoretical understanding of the interrelationship between digitalization and drivers of production, consumption, and overall economic growth are strongly needed.

Third, given both the complexity as well as the rather limited prospects of digitalization for sufficient absolute decoupling, we suggest that research should also follow a "precautionary principle approach" and investigate alternative questions that may also-or maybe better-contribute to achieving sustainable development goals. Most notably, research may focus on the opportunities and limitations of digitalization to foster growth-independent development, i.e., "post-growth" or "degrowth" economic development, e.g., [20,22,168,169]. Such research on "digitalization and degrowth" would aim at realizing steep reductions in resource use and emissions, while making social wellbeing as well as the functionality of the economy more independent from continuous economic growth. For instance, research could focus on how digitalization enables cooperative or non-profit-oriented business cases or how digitalization can empower consumers to make better use of practices such as sharing, repairing, reusing, prosuming, and the like. However, even in a post-growth and sharing economy, a certain level of products and services still need to be produced and maintained. Hence, we suggest to also follow alternative concepts, i.e., how digitalization can advance the prospects for a "circular economy" or even "circular society" [170-173].

Fourth, and with regard to conclusions relevant for policy-makers and other practitioners, our paper suggests that believing in the assumption that digitalization by itself will lead to sufficient absolute decoupling may be short-sighted. However, if political measures and instruments, business initiatives, and user behavior focus on realizing the saving potentials of ICT while countervailing energy- and resource-intensive hardware production as well as energy- and data-intensive applications, this can strongly improve ICT's contributions to achieving sustainable development goals.

Author Contributions: Conceptualization: S.L. and T.S.; investigation: S.L., J.P., and T.S.; writing一original draft preparation, S.L., J.P., and T.S.; writing-review and editing, S.L., J.P., and T.S.; funding acquisition, T.S. All authors have read and agreed to the published version of the manuscript.

Funding: This research was funded by the German Federal Ministry of Education and Research, grant number 01UU1607B.

Acknowledgments: We would like to thank Manuel Brümmer for excellent research assistance in the manuscript preparation.

Conflicts of Interest: The authors declare no conflict of interest. The funders had no role in the design of the study; in the collection, analyses, or interpretation of data; in the writing of the manuscript; or in the decision to publish the results.

\section{References}

1. Fischer-Kowalski, M.; von Weizsäcker, E.U.; Ren, Y.; Moriguchi, Y.; Crane, W.; Krausmann, F.; Eisenmenger, N.; Giljum, S.; Hennicke, P.; Romero Lankao, P.; et al. Decoupling Natural Resource Use and Environmental Impacts from Economic Growth; UNEP, Working Group on Decoupling to the International Resource Panel: Nairobi, Kenya; Paris, France, 2011; Available online: http://www.gci.org.uk/Documents/Decoupling_Report_English. pdf (accessed on 7 September 2020).

2. IPCC. Climate Change 2014: Synthesis Report; Core Writing Team, Pachauri, R.K., Meyer, L., Eds.; IPCC: Geneva, Switzerland, 2014; ISBN 978-92-9169-143-2.

3. Rockström, J.; Steffen, W.L.; Noone, K.; Persson, Å.; Chapin, F.S., III; Lambin, E.; Lenton, T.M.; Scheffer, M.; Folke, C.; Schellnhuber, H.J.; et al. Planetary boundaries: Exploring the safe operating space for humanity. Ecol. Soc. 2009, 14, 32. [CrossRef] 
4. Van den Bergh, J.; Kallis, G. Growth, A-Growth or Degrowth to Stay within Planetary Boundaries? J. Econ. Issues 2012, 46, 909-920. [CrossRef]

5. Victor, P.A. Managing without Growth: Slower by Design, Not Disaster; Edward Elgar Publishing: Cheltenham, UK, 2008; ISBN 1-84844-299-8.

6. Seidl, I.; Zahrnt, A. Postwachstumsgesellschaft: Konzepte für die Zukunft; Metropolis: Marburg, Germany, 2010; ISBN 3-89518-811-5.

7. Ekins, P. Economic Growth and Environmental Sustainability: The Prospects for Green Growth; Routledge: London, UK, 2000; Available online: https://www.taylorfrancis.com/books/9780203011751 (accessed on 7 September 2020).

8. OECD. A Green Growth Strategy for Food and Agriculture; OECD: Paris, France, 2011; Available online: http://www.oecd.org/greengrowth/sustainable-agriculture/48224529.pdf (accessed on 7 September 2020).

9. UNEP. Towards a Green Economy: Pathways to Sustainable Development and Poverty Eradication; UNEP: Nairobi, Kenya, 2011; ISBN 978-92-807-3143-9.

10. von Weizsäcker, E.U.; Hargroves, K.; Smith, M.; Desha, C.; Stasinopoulos, P. Factor Five: Transforming the Global Economy through 80\% Improvements in Resource Productivity: A Report to the Club of Rome; Earthscan/The Natural Edge Project: London, UK; Sterling, VA, USA, 2009; ISBN 978-1-84407-591-1.

11. Sorman, A.H.; Giampietro, M. The energetic metabolism of societies and the degrowth paradigm: Analyzing biophysical constraints and realities. J. Clean. Prod. 2013, 38, 80-93. [CrossRef]

12. Kallis, G.; Kalush, M.; O’Flynn, H.; Rossiter, J.; Ashford, N. 'Friday off': Reducing working hours in Europe. Sustainability 2013, 5, 1545-1567. [CrossRef]

13. Frey, B.S.; Stutzer, A. What can economists learn from happiness research? J. Econ. Lit. 2002, 40, 402-435. [CrossRef]

14. Kallis, G. In defence of degrowth. Ecol. Econ. 2011, 70, 873-880. [CrossRef]

15. Von Weizsäcker, E.U.; Aloisi de Larderel, J.; Hargroves, K.; Hudson, C.; Smith, M.H.; Enríquez, M.A. Decoupling 2: Technologies, Opportunities and Policy Options; UNEP, Working Group on Decoupling to the International Resource Panel: Nairobi, Kenya; Paris, France, 2014; Available online: http://wedocs.unep.org/ handle/20.500.11822/8892 (accessed on 7 September 2020).

16. Antal, M.; van den Bergh, J. Green growth and climate change: Conceptual and empirical considerations. Clim. Policy 2016, 16, 165-177. [CrossRef]

17. Johnson, I. Decoupling-A Response to Limits of Growth: A Project Proposed by the Club of Rome; Club of Rome: Winterthur, Switzerland, 2013.

18. Conrad, E.; Cassar, L. Decoupling Economic Growth and Environmental Degradation: Reviewing Progress to Date in the Small Island State of Malta. Sustainability 2014, 6, 6729-6750. [CrossRef]

19. Ekins, P.; Hughes, N. Resource Efficieny: Potential and Economic Implications. A report of the International Resource Panel; UNEP: Nairobi, Kenya, 2017; Available online: https://www.resourcepanel.org/sites/default/files/documents/ document/media/resource_efficiency_report_march_2017_web_res.pdf (accessed on 7 September 2020).

20. Jackson, T. Prosperity without Growth: Economics for a Finite Planet; Earthscan, from Routledge: London, UK, 2011; ISBN 978-1-84407-894-3.

21. Santarius, T. Der Rebound-Effekt: Ökonomische, Psychische und Soziale Herausforderungen für die Entkopplung von Wirtschaftswachstum und Energieverbrauch; Wirtschaftswissenschaftliche Nachhaltigkeitsforschung; Metropolis-Verlag: Marburg, Germany, 2015; ISBN 978-3-7316-1176-9.

22. Lange, S. Macroeconomics without Growth: Sustainable Economies in Neoclassical, Keynesian and Marxian Theories; Wirtschaftswissenschaftliche Nachhaltigkeitsforschung; Metropolis: Marburg, Germany, 2018; ISBN 978-3-7316-1298-8.

23. Alexander, S. Post-growth economics: A paradigm shift in progress. Arena J. 2014, 41/42, 93-122.

24. Lange, S. Beyond A-Growth: Sustainable Zero Growth. In Handbook on Global Sustainability Governance; Routledge: London, UK, 2019; pp. 322-333.

25. Van den Bergh, J. Environment versus growth-A criticism of "degrowth" and a plea for "a-growth". Ecol. Econ. 2011, 70, 881-890. [CrossRef]

26. D'Alessandro, S.; Cieplinski, A.; Distefano, T.; Dittmer, K. Feasible alternatives to green growth. Nat. Sustain. 2020, 1-7. [CrossRef]

27. Lange, S.; Santarius, T. Smart Green World? Making Digitalization Work for Sustainability; Routledge: Abington, UK, 2020; ISBN 978-0-367-46761-6. 
28. GeSI; Accenture. Smarter 2030. ICT Solutions for 21st Century Challenges; GeSI: Brussels, Belgium, 2015.

29. Hilty, L.M. Why energy efficiency is not sufficient-some remarks on Green by IT. In Proceedings of the EnviroInfo 2012; Arndt, H.K., Ed.; Federal Environment Agency: Dessau, Germany, 2012; pp. 13-20.

30. Hilty, L.M.; Aebischer, B. ICT Innovations for Sustainability; Advances in Intelligent Systems and Computing; Springer International Publishing: Cham, Switzerland, 2015; Volume 310, ISBN 978-3-319-09227-0.

31. Daly, H.E. Steady-State Economics, 2nd ed.; Island Press: Washington, DC, USA, 1991.

32. Santarius, T. Entkopplung. In Wörterbuch Klimadebatte; Bauriedl, S., Ed.; Transcript: Bielefeld, Germany, 2015; pp. 81-86.

33. OECD. OECD Digital Economy Outlook 2017; OECD Publishing: Paris, France, 2017; Available online: https://www.oecd.org/internet/oecd-digital-economy-outlook-2017-9789264276284-en.htm (accessed on 7 September 2020).

34. Mas, M.; Fernandez de Guevara Radoselovics, J.; Robledo, J.C.; Righi, R.; Cardona, M.; Samoili, S.; De Prato, G.; Lopez Cobo, M. The 2019 PREDICT Key Facts Report: An Analysis of ICT RED in the EU and Beyond; Publications Office of the European Union: Luxembourg, 2019; Available online: https: //ideas.repec.org/p/ipt/iptwpa/jrc116987.html (accessed on 7 September 2020).

35. Meadows, D.H.; Meadows, D.L.; Zahn, E.K.O.; Milling, P. Limits to Growth: A Report for the Club of Rome's Project on the Predicament of Mankind; New Amer Library: New York, NY, USA, 1972; ISBN 978-0-451-13695-4.

36. Groth, C. A new-growth perspective on non-renewable resources. In Sustainable Resource Use and Economic Dynamics; Bretschger, L., Smulders, S., Eds.; Springer: Dordrecht, The Netherlands, 2007; pp. 127-163.

37. Dasgupta, P.; Heal, G. The optimal depletion of exhaustible resources. Rev. Econ. Stud. 1974, 41, 3-28. [CrossRef]

38. Solow, R.M. Intergenerational equity and exhaustible resources. Rev. Econ. Stud. 1974, 41, 29-45. [CrossRef]

39. Panayotou, T.; Peterson, A.; Sachs, J.D. Is the Environmental Kuznets Curve Driven by Structural Change? What Extended Time Series May Imply for Developing Countries. CAER II Discuss. Pap. 2000. [CrossRef]

40. Marsiglio, S.; Ansuategi, A.; Gallastegui, M.C. The Environmental Kuznets Curve and the Structural Change Hypothesis. Environ. Resour. Econ. 2016, 63, 265-288. [CrossRef]

41. Stern, D.I. The rise and fall of the Environmental Kuznets Curve. World Dev. 2004, 32, 1419-1439. [CrossRef]

42. Kuznets, S. Economic growth and income inequality. Am. Econ. Rev. 1955, 45, 1-28.

43. Arrow, K.; Bolin, B.; Costanza, R.; Dasgupta, P.; Folke, C.; Holling, C.S.; Jansson, B.O.; Levin, S.; Mäler, K.G.; Perrings, C.; et al. Economic Growth, Carrying Capacity, and the Environment. Ecol. Appl. 1996, 6, 13-15. [CrossRef]

44. Parrique, T.; Barth, J.; Briens, F.; Kerschner, C.; Kraus-Polk, A.; Kuokkanen, A.; Spangenberg, J.H. Decoupling Debunked-Evidence and Arguments against Green Growth as a Sole Strategy for Sustainability; European Environmental Bureau: Brussels, Belgium, 2019; Available online: https://eeb.org/library/decouplingdebunked/ (accessed on 7 September 2020).

45. Dinda, S. Environmental Kuznets Curve Hypothesis: A Survey. Ecol. Econ. 2004, 49, 431-455. [CrossRef]

46. Grossman, G.; Krueger, A. Economic growth and the environment. Q. J. Econ. 1995, 110, 353-377. [CrossRef]

47. Selden, T.M.; Song, D. Environmental quality and development: Is there a Kuznets Curve for air pollution emissions? J. Environ. Econ. Manag. 1994, 27, 147-162. [CrossRef]

48. Yandle, B.; Vijayaraghavan, M.; Bhattarai, M. The Environmental Kuznets Curve: A primer. Prop. Environ. Res. Cent. Study 2002, 2, 1-24.

49. Smulders, S.; Toman, M.; Withagen, C. Growth theory and 'green growth'. Oxf. Rev. Econ. Policy 2014, 30, 423-446. [CrossRef]

50. Caviglia-Harris, J.; Chambers, D.; Kahn, J. Taking the 'U' out of Kuznets. Ecol. Econ. 2009, 68, 1149-1159. [CrossRef]

51. Markandya, A.; Perelet, R.; Mason, P.; Taylor, T. Dictionary of Environmental Economics; Earthscan: London, UK, 2002; Available online: https://www.taylorfrancis.com/books/9781849774253 (accessed on 7 September 2020).

52. IEA. Key World Energy Statistics 2017; IEA: Paris, France, 2017; Available online: http://svenskvindenergi.org/ wp-content/uploads/2017/12/KeyWorld2017.pdf (accessed on 7 September 2020).

53. Brookes, L. Energy policy, the energy price fallacy and the role of nuclear energy in the UK. Energy Policy 1978, 6, 94-106. [CrossRef]

54. Schurr, S.H. Energy efficiency and productive efficiency: Some thoughts based on American experience. Energy J. 1982, 3, 3-14. [CrossRef] 
55. Lange, S.; Pohl, J.; Santarius, T. Digitalization and Energy Consumption. Does ICT Reduce Energy Demand? Ecol. Econ. 2020, 176, 106760. [CrossRef]

56. Stern, D. The Role of Energy in Economic Growth. Ann. N. Y. Acad. Sci. 2011, 1219, 26-51. [CrossRef] [PubMed]

57. Ayres, R.U. Exergy, power and work in the US economy, 1900-1998. Energy 2003, 28, 219-273. [CrossRef]

58. Kümmel, R. The Second Law of Economics: Energy, Entropy, and the Origins of Wealth; Springer: New York, NY, USA, 2011; ISBN 978-1-4419-9365-6.

59. Stern, D.I.; Kander, A. The Role of Energy in the Industrial Revolution and Modern Economic Growth. Energy J. 2012, 33, 127-154. [CrossRef]

60. Daly, H.E. Toward some operational principles of sustainable development. Ecol. Econ. 1990, 2, 1-6. [CrossRef]

61. Apostolakis, B.E. Energy-Capital substitutability/complementarity. Energy Econ. 1990, 12, 48-58. [CrossRef]

62. Broadstock, D.; Hunt, L.; Sorrell, S. UKERC Review of Evidence for the Rebound Effect; UK Energy Research Centre: London, UK, 2007; Available online: https://ukerc.ac.uk/publications/ukerc-review-of-evidence-forthe-rebound-effect-technical-report-3-elasticity-of-substitution-studies/ (accessed on 7 September 2020).

63. Alcott, B. Jevons' paradox. Ecol. Econ. 2005, 54, 9-21. [CrossRef]

64. Khazzoom, J.D. Economic implications of mandated efficiency in standards for household appliances. Energy J. 1980, 1, 21-40.

65. Santarius, T.; Walnum, H.J.; Aall, C. Rethinking Climate and Energy Policies: New Perspectives on the Rebound Phenomenon; Springer International Publishing: Cham, Switzerland, 2016; ISBN 978-3-319-38807-6.

66. Ayres, R.U.; Warr, B. The Economic Growth Engine: How Energy and Work Drive Material Prosperity; Edward Elgar: Cheltenham, UK, 2009; ISBN 978-1-84844-182-8.

67. Fouquet, R. Heat, Power and Light: Revolutions in Energy Services; Edward Elgar Publishing: Cheltenham, UK, 2008; ISBN 1-78254-252-3.

68. Jenkins, J.; Nordhaus, T.; Shellenberger, M. Energy Emergence: Rebound and Backfire as Emergent Phenomena; Breakthrough Institute: Oakland, CA, USA, 2011.

69. Saunders, H.D. The Khazzoom-Brookes postulate and neoclassical growth. Energy J. 1992, 13, $131-148$. [CrossRef]

70. Saunders, H.D. A view from the macro side: Rebound, backfire, and Khazzoom-Brookes. Energy Policy 2000, 28, 439-449. [CrossRef]

71. Gillingham, K.; Newell, R.G.; Palmer, K. Energy Efficiency Economics and Policy; National Bureau of Economic Research: Cambridge, MA, USA, 2009.

72. Goldstein, D.; Martinez, S.; Roy, R. Are There Rebound Effects from Energy Efficiency? An Analysis of Empirical Data, Internal Consistency, and Solutions. 2011. Available online: https:/grist.org/wp-content/ uploads/2011/05/rebound-5-7-2011-final.pdf (accessed on 7 September 2020).

73. Nadel, S. The Rebound Effect: Large or Small? American Council for an Energy-Efficient Economy: Washington, DC, USA, 2012.

74. Schipper, L.; Grubb, M. On the rebound? Feedback between energy intensities and energy uses in IEA countries. Energy Policy 2000, 28, 367-388. [CrossRef]

75. Azevedo, I.L.; Sonnberger, M.; Thomas, B.A.; Morgan, G.; Renn, O. The Need to Account for Consumer Behaviour in order to Develop Robust Energy Efficiency Policies. In A Review of the Literature on the Rebound Effect in Energy Efficiency and Report from Expert Workshops; International Risk Governance Council: Geneva, Switzerland, 2012.

76. Greening, L.A.; Greene, D.L.; Difiglio, C. Energy efficiency and consumption-The rebound effect-A survey. Energy Policy 2000, 28, 389-401. [CrossRef]

77. Maxwell, D.; Owen, P.; McAndrew, L. Addressing the rebound effect. European Commission DG Environment. Molden, D. and Sakthivadivel, R. (1999) Water accounting to assess use and productivity of water. Int. J. Water Resour. Dev. 2011, 15, 55-71.

78. Sorrell, S. Energy, Economic Growth and Environmental Sustainability: Five Propositions. Sustainability 2010, 2, 1784-1809. [CrossRef]

79. Lipsey, R.G.; Carlaw, K.I.; Bekar, C.T. Economic Transformations: General Purpose Technologies and Long-Term Economic Growth; Oxford University Press: New York, NY, USA, 2005. 
80. Bresnahan, T.F.; Trajtenberg, M. General purpose technologies 'Engines of growth'? J. Econom. 1995, 65, 83-108. [CrossRef]

81. Bieser, J.C.T.; Hilty, L.M. Indirect Effects of the Digital Transformation on Environmental Sustainability: Methodological Challenges in Assessing the Greenhouse Gas Abatement Potential of ICT. In Proceedings of the ICT4S2018. 5th International Conference on Information and Communication Technology for Sustainability (ICT4S2018), Toronto, ON, Canada, 14-18 May 2018; pp. 68-81. [CrossRef]

82. Malmodin, J.; Bergmark, P. Exploring the Effect of ICT Solutions on GHG Emissions in 2030. In Proceedings of the 29th International Conference on Informatics for Environmental Protection and the Third International Conference on ICT for Sustainability, EnviroInfo \& ICT4S 2015, Copenhagen, Denmark, 7-9 September 2015.

83. Marscheider-Weidemann, F.; Langkau, S.; Hummen, T.; Erdmann, L.; Tercero Espinoza, L.A.; Angerer, G.; Marwede, M.; Benecke, S. Rohstoffe für Zukunftstechnologien 2016: Auftragsstudie; DERA Rohstoffinformationen; Fraunhofer Institut für System-und Innovationsforschung: Berlin, Germany, 2016; ISBN 978-3-943566-72-7.

84. Malmodin, J.; Bergmark, P.; Matinfar, S. A high-level estimate of the material footprints of the ICT and the E\&M sector. In Proceedings of the ICT4S2018, 5th International Conference on Information and Communication Technology for Sustainability (ICT4S2018), Toronto ON, Canada, 14-18 May 2018.

85. Henckens, M.L.C.M.; Driessen, P.P.J.; Worrell, E. Metal scarcity and sustainability, analyzing the necessity to reduce the extraction of scarce metals. Resour. Conserv. Recycl. 2014, 93, 1-8. [CrossRef]

86. $\mathrm{Ku}, \mathrm{A} . Y$. Anticipating critical materials implications from the Internet of Things (IOT): Potential stress on future supply chains from emerging data storage technologies. Sustain. Mater. Technol. 2018, 15, 27-32. [CrossRef]

87. Vaalma, C.; Buchholz, D.; Weil, M.; Passerini, S. A cost and resource analysis of sodium-ion batteries. Nat. Rev. Mater. 2018, 3, 18013. [CrossRef]

88. Pavel, C.C.; Marmier, A.; Tzimas, E.; Schleicher, T.; Schüler, D.; Buchert, M.; Blagoeva, D. Critical raw materials in lighting applications: Substitution opportunities and implication on their demand: Critical raw materials in lighting applications. Phys. Status Solidi A 2016, 213, 2937-2946. [CrossRef]

89. Pavel, C.C.; Thiel, C.; Degreif, S.; Blagoeva, D.; Buchert, M.; Schüler, D.; Tzimas, E. Role of substitution in mitigating the supply pressure of rare earths in electric road transport applications. Sustain. Mater. Technol. 2017, 12, 62-72. [CrossRef]

90. Pavel, C.C.; Lacal-Arántegui, R.; Marmier, A.; Schüler, D.; Tzimas, E.; Buchert, M.; Jenseit, W.; Blagoeva, D. Substitution strategies for reducing the use of rare earths in wind turbines. Resour. Policy 2017, 52, 349-357. [CrossRef]

91. European Commission. The Digital Agenda for Europe-Driving European Growth Digitally; European Commission: Brussels, Belgium, 2012.

92. Manyika, J.; Dobbs, R.; Chui, M.; Bughin, J.; Bisson, P.; Woetzel, J. The Internet of Things: Mapping the Value bEyond the Hype; McKinsey Global Institute: San Francisco, CA, USA, 2016.

93. OECD. OECD Digital Economy Outlook 2015; OECD Publishing: Paris, France, 2015; ISBN 978-92-64-23227-3.

94. Sapprasert, K. The Impact of ICT on the Growth of the Service Industries; Working Papers on Innovation Studies; Centre for Technology, Innovation and Culture, University of Oslo: Oslo, Norway, 2010.

95. Boston Consulting Group. Industry 4.0: The Future of Productivity and Growth in Manufacturing Industries; Boston Consulting Group: Boston, MA, USA, 2015.

96. Cornia, G.A. The impact of liberalisation and globalisation on within-country income inequality. CESifo Econ. Stud. 2003, 49, 581-616. [CrossRef]

97. Sachs, W.; Santarius, T. Fair Future. Limited Resources and Global Justice; Zed Books: London, UK, 2007.

98. Schiller, D. Digital Capitalism: Networking the Global Market System; 1. paperback; MIT Press: Cambridge, MA, USA; London, UK, 2000; ISBN 978-0-262-19417-4.

99. Ferdinand, J.-P.; Petschow, U.; Dickel, S. The Decentralized and Networked Future of Value Creation; Progress in IS; Springer International Publishing: Cham, Switzerland, 2016; ISBN 978-3-319-31684-0.

100. Gebler, M.; Schoot Uiterkamp, A.J.M.; Visser, C. A global sustainability perspective on 3D printing technologies. Energy Policy 2014, 74, 158-167. [CrossRef]

101. Rayna, T.; Striukova, L. From rapid prototyping to home fabrication: How 3D printing is changing business model innovation. Technol. Forecast. Soc. Chang. 2016, 102, 214-224. [CrossRef]

102. Atkinson, L. Smart shoppers? Using QR codes and 'green' smartphone apps to mobilize sustainable consumption in the retail environment: Smart shoppers? Int. J. Consum. Stud. 2013, 37, 387-393. [CrossRef] 
103. Brauer, B.; Ebermann, C.; Hildebrandt, B.; Remané, G.; Kolbe, L.M. Green by App: The Contribution of Mobile Applications to Environmental Sustainability. In Proceedings of the Pacific Asia Conference on Information Systems, Chiayi, Taiwan, 27 June-1 July 2016; pp. 1-16.

104. Luck, E.; Ginanti, A. Online environmental citizenship: Blogs, green marketing and consumer sentiment in the 21st Century. Electron. Green J. 2013, 1, 1-26. [CrossRef]

105. Börjesson Rivera, M.; Håkansson, C.; Svenfelt, Å.; Finnveden, G. Including second order effects in environmental assessments of ICT. Environ. Model. Softw. 2014, 56, 105-115. [CrossRef]

106. Svenfelt, A.; Zapico, J.L. Sustainable Food Systems with ICT; Atlantis Press: Paris, France, 2016.

107. Zapico, J.L.; Brandt, N.; Turpeinen, M. Environmental Metrics: The Main Opportunity from ICT for Industrial Ecology. J. Ind. Ecol. 2010, 14, 703-706. [CrossRef]

108. Büyüközkan, G.; Göçer, F. Digital Supply Chain: Literature review and a proposed framework for future research. Comput. Ind. 2018, 97, 157-177. [CrossRef]

109. Geissbauer, R.; Lübben, E.; Schrauf, S.; Pillsbury, S. Global Digital Operations Study; PriceWaterhouseCoopers: Munich, Germany, 2018.

110. Hankammer, S.; Hora, M.; Canetta, L.; Kaygin Sel, S. User-Interface Design for Individualization Services to Enhance Sustainable Consumption and Production. Procedia Cirp. 2016, 47, 448-453. [CrossRef]

111. Kannan, P.K.; Li, H. "Alice” Digital marketing: A framework, review and research agenda. Int. J. Res. Mark. 2017, 34, 22-45. [CrossRef]

112. Von Hippel, E. Democratizing innovation: The evolving phenomenon of user innovation. Int. J. Innov. Sci. 2009, 1, 29-40. [CrossRef]

113. Abrahamse, W.; Steg, L.; Vlek, C.; Rothengatter, T. A review of intervention studies aimed at household energy conservation. J. Environ. Psychol. 2005, 25, 273-291. [CrossRef]

114. Osbaldiston, R.; Schott, J.P. Environmental Sustainability and Behavioral Science: Meta-Analysis of Proenvironmental Behavior Experiments. Environ. Behav. 2012, 44, 257-299. [CrossRef]

115. Chan, T.K.H.; Cheung, C.M.K.; Lee, Z.W.Y. The state of online impulse-buying research: A literature analysis. Inf. Manag. 2017, 54, 204-217. [CrossRef]

116. Lohmann, S. Information technologies and subjective well-being: Does the Internet raise material aspirations? Oxf. Econ. Pap. 2015, 67, 740-759. [CrossRef]

117. Pappas, I.O.; Kourouthanassis, P.E.; Giannakos, M.N.; Chrissikopoulos, V. Shiny happy people buying: The role of emotions on personalized e-shopping. Electron. Mark. 2014, 24, 193-206. [CrossRef]

118. Zhang, K.Z.K.; Benyoucef, M. Consumer behavior in social commerce: A literature review. Decis. Support Syst. 2016, 86, 95-108. [CrossRef]

119. Andrae, A.S.G.; Edler, T. On Global Electricity Usage of Communication Technology: Trends to 2030. Challenges 2015, 6, 117-157. [CrossRef]

120. Belkhir, L.; Elmeligi, A. Assessing ICT global emissions footprint: Trends to 2040 \& recommendations. J. Clean. Prod. 2018, 177, 448-463. [CrossRef]

121. Van Heddeghem, W.; Lambert, S.; Lannoo, B.; Colle, D.; Pickavet, M.; Demeester, P. Trends in worldwide ICT electricity consumption from 2007 to 2012. Comput. Commun. 2014, 50, 64-76. [CrossRef]

122. Andrae, A.S.G. Projecting the chiaroscuro of the electricity use of communication and computing from 2018 to 2030. Preprint 2019, 1-23. [CrossRef]

123. Malmodin, J.; Lundén, D. The energy and carbon footprint of the global ICT and E\&M sectors 2010-2015. Sustainability 2018, 10, 3027.

124. Salahuddin, M.; Alam, K. Information and Communication Technology, electricity consumption and economic growth in OECD countries: A panel data analysis. Int. J. Electr. Power Energy Syst. 2016, 76, 185-193. [CrossRef]

125. Saidi, K.; Toumi, H.; Zaidi, S. Impact of Information Communication Technology and Economic Growth on the Electricity Consumption: Empirical Evidence from 67 Countries. J. Knowl. Econ. 2015. [CrossRef]

126. Sadorsky, P. Information communication technology and electricity consumption in emerging economies. Energy Policy 2012, 48, 130-136. [CrossRef]

127. Ishida, $\mathrm{H}$. The effect of ICT development on economic growth and energy consumption in Japan. Telemat. Inform. 2015, 32, 79-88. [CrossRef]

128. Schulte, P.; Welsch, H.; Rexhäuser, S. ICT and the Demand for Energy: Evidence from OECD Countries. Environ. Resour. Econ. 2016, 63, 119-146. [CrossRef] 
129. Khayyat, N.T.; Lee, J.; Heo, E. How ICT investment influences energy demand in South Korea and Japan. Energy Effic. 2016, 9, 563-589. [CrossRef]

130. OECD. World Energy Outlook 2017; OECD Publishing: Paris, France, 2017; ISBN 978-92-64-28230-8.

131. Mickoleit, A. Greener and Smarter: ICTs, the Environment and Climate Change; OECD: Paris, France, 2010.

132. Sui, D.Z.; Rejeski, D.W. Environmental Impacts of the Emerging Digital Economy: The E-for-Environment E-Commerce? Environ. Manag. 2002, 29, 155-163. [CrossRef]

133. Berkhout, F.; Hertin, J. Impacts of Information and Communication Technologies on Environmental Sustainability: Speculations and Evidence. Report to the OECD; SPRU: Falmer, UK, 2001.

134. Accenture Circular Advantage. Innovative Business Models and Technologies to Create Value in a World without Limits to Growth 2014. Available online: https://www.accenture.com/t20150523T053139_w_/ us-en/_acnmedia/Accenture/Conversion-Assets/DotCom/Documents/Global/PDF/Strategy_6/AccentureCircular-Advantage-Innovative-Business-Models-Technologies-Value-Growth.pdf (accessed on 7 September 2020).

135. Boston Consulting Group. SMART 2020 Addendum Deutschland: Die IKT-Industrie als treibende Kraft auf dem Weg zu Nachhaltigem Klimaschutz; Boston Consulting Group: Boston, MA, USA, 2009.

136. GeSI; Accenture. Enabling the Global Goals: Evidence of Digital Solutions' Impact on Achieving the Sustainable Development Goals (SDGs); GeSI: Berlin, Germany, 2018.

137. Coroama, V.C.; Hilty, L.M.; Birtel, M. Effects of Internet-based multiple-site conferences on greenhouse gas emissions. Telemat. Inform. 2012, 29, 362-374. [CrossRef]

138. Moberg, Å.; Borggren, C.; Finnveden, G.; Tyskeng, S. Environmental impacts of electronic invoicing. Prog. Ind. Ecol. Int. J. 2010, 7, 93-113. [CrossRef]

139. Moberg, Å.; Johansson, M.; Finnveden, G.; Jonsson, A. Printed and tablet e-paper newspaper from an environmental perspective-A screening life cycle assessment. Environ. Impact Assess. Rev. 2010, 30, 177-191. [CrossRef]

140. Seetharam, A.; Somasundaram, M.; Towsley, D.; Kurose, J.; Shenoy, P. Shipping to Streaming: Is this shift green? In Proceedings of the First ACM SIGCOMM Workshop on Green Networking, New Delhi, India, 30 August 2010; ACM: New York, NY, USA, 2010; pp. 61-68.

141. Shehabi, A.; Walker, B.; Masanet, E. The energy and greenhouse-gas implications of internet video streaming in the United States. Environ. Res. Lett. 2014, 9, 054007. [CrossRef]

142. Beier, G.; Niehoff, S.; Xue, B. More Sustainability in Industry through Industrial Internet of Things? Appl. Sci. 2018, 8, 219. [CrossRef]

143. Williams, E.; Tagami, T. Energy Use in Sales and Distribution via E-Commerce and Conventional Retail: A Case Study of the Japanese Book Sector. J. Ind. Ecol. 2002, 6, 99-114. [CrossRef]

144. Horner, N.C.; Shehabi, A.; Azevedo, I.L. Known unknowns: Indirect energy effects of information and communication technology. Environ. Res. Lett. 2016, 11, 103001. [CrossRef]

145. Mangiaracina, R.; Marchet, G.; Perotti, S.; Tumino, A. A review of the environmental implications of B2C e-commerce: A logistics perspective. Int. J. Phys. Distrib. Logist. Manag. 2015, 45, 565-591. [CrossRef]

146. Van Loon, P.; Deketele, L.; Dewaele, J.; McKinnon, A.; Rutherford, C. A comparative analysis of carbon emissions from online retailing of fast moving consumer goods. J. Clean. Prod. 2015, 106, 478-486. [CrossRef]

147. Berkhout, F.; Hertin, J. De-materialising and re-materialising: Digital technologies and the environment. Futures 2004, 36, 903-920. [CrossRef]

148. Hilty, L.M.; Aebischer, B.; Rizzoli, A.E. Modeling and evaluating the sustainability of smart solutions. Environ. Model. Softw. 2014, 56,1-5. [CrossRef]

149. Pohl, J.; Hilty, L.M.; Finkbeiner, M. How LCA contributes to the environmental assessment of higher order effects of ICT application: A review of different approaches. J. Clean. Prod. 2019, 219, 698-712. [CrossRef]

150. Gossart, C. Rebound effects and ICT: A review of the literature. In ICT Innovations for Sustainability. Advances in Intelligten Systems and Computing 310; Hilty, L.M., Aebischer, B., Eds.; Springer: Berlin/Heidelberg, Germany, 2015; pp. 435-448.

151. Katz, R.L.; Koutroumpis, P. Measuring digitization: A growth and welfare multiplier. Technovation 2013, 33, 314-319. [CrossRef]

152. Farhadi, M.; Ismail, R.; Fooladi, M. Information and communication technology use and economic growth. PLoS ONE 2012, 7, e48903. [CrossRef] 
153. Jorgenson, D.W.; Ho, M.S.; Samuels, J.D. The impact of information technology on postwar US economic growth. Telecommun. Policy 2016, 40, 398-411. [CrossRef]

154. Lee, J.W.; Brahmasrene, T. ICT, $\mathrm{CO}_{2}$ Emissions and Economic Growth: Evidence from a Panel of ASEAN. Glob. Econ. Rev. 2014, 43, 93-109. [CrossRef]

155. Hofman, A.; Aravena, C.; Aliaga, V. Information and communication technologies and their impact in the economic growth of Latin America, 1990-2013. Telecommun. Policy 2016, 40, 485-501. [CrossRef]

156. Acemoglu, D.; Restrepo, P. The Race between Machine and Man: Implications of Technology for Growth, Factor Shares and Employment; National Bureau of Economic Research: Cambridge, MA, USA, 2016.

157. McKinsey. The Internet of Things: Mapping the Value Beyond the Hype; McKinsey Global Institute: San Francisco, CA, USA, 2015.

158. Brynjolfsson, E.; McAfee, A. The Second Machine Age: Work, Progress, and Prosperity in a Time of Brilliant Technologies; Norton \& Company: New York, NY, USA, 2014; ISBN 0-393-35064-9.

159. Degryse, C. Digitalisation of the Economy and its Impact on Labour Markets; ETUI: Brüssel, Belgium, 2016.

160. Frey, C.B.; Osborne, M.A. The Future of Employment: How Susceptible Are Jobs to Computerisation? Oxford Martin School, University of Oxford: Oxford, UK, 2013.

161. OECD. ICTs and Jobs: Complements or Substitutes? The Effects of ICT Investment on Labour Market Demand by Skills and by Industry in Selected OECD Countries; OECD Digital Economy Papers; OECD: Paris, France, 2016.

162. Staab, P. Falsche Versprechen: Wachstum im Digitalen Kapitalismus; Kleine Reihe; Hamburger Edition HIS: Hamburg, Germany, 2016; ISBN 978-3-86854-305-6.

163. Castiglione, C.; Infante, D. ICT as general purpose technologies: A micro-econometric investigation on Italian firms. Int. J. Trade Glob. Mark. 2013, 6, 225-241. [CrossRef]

164. Liao, H.; Wang, B.; Li, B.; Weyman-Jones, T. ICT as a general-purpose technology: The productivity of ICT in the United States revisited. Inf. Econ. Policy 2016, 36, 10-25. [CrossRef]

165. Van den Bergh, J.C.J.M. Energy Conservation More Effective with Rebound Policy. Environ. Resour. Econ. 2011, 48, 43-58. [CrossRef]

166. Walnum, H.J.; Andrae, A.S.G. The Internet: Explaining ICT Service Demand in Light of Cloud Computing Technologies. In Rethinking Climate and Energy Policies: New Perspectives on the Rebound Phenomenon; Santarius, T., Walnum, J.H., Aall, C., Eds.; Springer International Publishing: Cham, Switzerland, 2016; pp. 227-241. ISBN 978-3-319-38807-6.

167. Jovanovic, B.; Rousseau, P.L. General Purpose Technologies. In Handbook of Economic Growth; Elsevier: Amsterdam, The Netherlands, 2005; Volume 1, pp. 1181-1224. ISBN 978-0-444-52043-2.

168. D'Alisa, G.; Demaria, F.; Kallis, G. Degrowth: A Vocabulary for a New Era; Routledge: New York, NY, USA; London, UK, 2014; ISBN 1-134-44977-1.

169. Heinberg, R. The End of Growth: Adapting to Our New Economic Reality; New Society Publishers: Gabriola Island, BC, Canada, 2011.

170. Bocken, N.; Short, S.W. Transforming Business Models: Towards a Sufficiency-based Circular Economy. In Handbook of the Circular Economy; Brandão, M., Lazarevic, D., Finnveden, G., Eds.; Edward Elgar Publishing: Cheltenham, UK, 2020.

171. Braungart, M.; McDonough, W. Cradle to Cradle: Remaking the Way We Make Things; Vintage: London, UK, 2002; ISBN 8580001060248.

172. Geissdoerfer, M.; Savaget, P.; Bocken, N.M.P.; Hultink, E.J. The Circular Economy-A new sustainability paradigm? J. Clean. Prod. 2017, 143, 757-768. [CrossRef]

173. Moula, M.E.; Sorvari, J.; Oinas, P. Constructing a Green Circular Society; Faculty of Social Sciences, University of Helsinki: Helsinki, Finland, 2017.

(C) 2020 by the authors. Licensee MDPI, Basel, Switzerland. This article is an open access article distributed under the terms and conditions of the Creative Commons Attribution (CC BY) license (http://creativecommons.org/licenses/by/4.0/). 